\title{
EFFECT OF XENON ON PAIN SEVERITY AND ADAPTATIONAL STATUS OF NEURO-ONCOLOGICAL AND ONCOGYNECOLOGICAL PATIENTS
}

\author{
N.N. Popova, M.S. Zinkovich, A.I. Shikhlyarova, G.V. Zhukova, L.Ya. Rozenko, T.P. Protasova, \\ A.S. Goncharova, M.I. Bragina \\ Rostov Research Institute of Oncology, Rostov-on-Don, Russia

\section{ВЛИЯНИЕ КСЕНОНА НА ВЫРАЖЕННОСТЬ БОЛЕВОГО СИНДРОМА И АДАПТАЦИОННЫЙ СТАТУС НЕЙРООНКОЛОГИЧЕСКИХ И ОНКОГИНЕКОЛОГИЧЕСКИХ БОЛЬНЫХ}

\author{
Н.Н. Попова, М.С. Зинькович, А.И. Шихлярова, Г.В. Жукова, Л.Я. Розенко, \\ Т.П. Протасова, А.С. Гончарова, М.И. Брагина
}

ФГБУ «Ростовский научно-исследовательский онкологический институт» Минздрава России, Ростов-на-Дону

\begin{abstract}
The severity of pain and changes in the adaptational status were studied in patients with brain metastases or cervical cancer receiving xenon therapy after whole brain radiotherapy or after radical hysterectomy. Hematological indicators of the nature and tensiton of general nonspecific adaptional reactions of the body (ARs) by Garkavi-Kvakina-Ukolova, the QLQ-C15 questionnaire and a 10-point graphic visual analogue scale for the assessment of the intensity of pain were used. Xenon caused concurrent reduce in the intensity of pain and improvement of characteristics of ARs in all studied patients. The results suggested an association between the analgesic effect of xenon and the normalization of neuroimmune processes and reduced damaging effects of special antitumor treatment on the body under the influence of xenon.
\end{abstract}

Keywords: malignant tumors; xenon; pain; adaptational reactions.

У пациентов с метастатическим поражением головного мозга и раком шейки матки изучали выраженность болевого синдрома и сдвиги адаптационного статуса при ксенонотерапии, на фоне радиотерапии и хирургического лечения. Использовали гематологические показатели характера и напряженности общих неспецифических адаптационных реакций организма (АР) по Гаркави - Квакиной - Уколовой, опросник качества жизни QLQ-C15 и 10-балльную графическую визуально-аналоговую шкалу для оценки интенсивности боли. У исследованных больных была отмечена связь снижения интенсивности болевых ощущений и улучшения характеристик АР. Сделан вывод о нормализации нейроиммунных процессов и ослаблении повреждающего действия специального противоопухолевого лечения под влиянием ксенона.

Ключевые слова: злокачественные опухоли; ксенон; боль; адаптационные реакции.

Background. The formation of the pain syndrome and malignant growth are associated with impaired neuroimmune relationships [2]. Xenon is reported to have neuroprotective and immunocorrective effects [3].

The aim of the study was to assess the association between an analgesic effect of xenon in cancer patients and changes in characteristics of adaptational reactions (AR), the development of which is caused by multi-level processes in the neuroendocrine and immune systems [1].

Material and methods. Indicators of the status were studied in 26 patients aged 39-70 years with solitary brain metastases (BM) from different primary tumors receiving radiotherapy (RT) after the removal of metastatic tumors. RT involved distant whole brain radiotherapy and a boost to the bed of removed metastasis 5 hours after the main RT. 10 of 26 patients received inhalations of a xenon- oxygen mixture twice a week during the whole RT cycle $(\mathrm{RT}+\mathrm{Xe})$.

30 patients with cervical cancer (CC), mean age $39.7 \pm 1.3$ years, were studied as well. All patients underwent radical hysterectomy under general anesthesia. 18 of 30 patients received a xenon therapy cycle ( 5 sessions) during the early postoperative period, without analgesics for at least 12 hours prior to the session. Other patients received standard therapy in the postoperative period.

Patients with BM mainly reported headaches, and CC patients reported pain at the surgical site. The severity of pain in patients with BM was determined using the QLQ-C15 questionnaire. A 10-point graphical visual analogue scale (VAS) was used to assess the intensity of pain in patients with CC $(0-$ no pain, 10 - maximal pain $)$. The adaptational status in all patients was evaluated by hematological parameters, first of all by the 
Table

Dynamics of pain severity, integrated indicator of the quality of life (QLQ-C15 questionnaire) and the adaptational status of patients with BM before and after RT cycle and xenon therapy

\begin{tabular}{|c|c|c|c|c|c|c|}
\hline \multirow{2}{*}{\multicolumn{3}{|c|}{ Indicator }} & \multicolumn{2}{|c|}{ RT $(n=16)$} & \multicolumn{2}{|c|}{$\mathrm{RT}+\mathrm{Xe}(n=10)$} \\
\hline & & & Before treatment & After treatment & Before treatment & After treatment \\
\hline \multicolumn{3}{|c|}{ Pain severity, score } & $28.4 \pm 2.4$ & $25.7 \pm 2.5$ & $33.3 \pm 3.9$ & $13.3 \pm 1.2^{*}$ \\
\hline \multirow{5}{*}{$\begin{array}{l}\text { Adaptational } \\
\text { status, \% of } \\
\text { cases }\end{array}$} & \multirow{3}{*}{$\begin{array}{l}\text { LRL and } \\
\text { VLRL }\end{array}$} & Stress & 20 & 37.5 & 20 & 20 \\
\hline & & RA & 0 & 6 & 20 & 0 \\
\hline & & $\begin{array}{l}\text { Anti-stress } \\
\text { ARs }\end{array}$ & 80 & 31 & 60 & 10 \\
\hline & \multicolumn{2}{|c|}{ Stress areactivity } & 0 & 25 & 0 & 50 \\
\hline & \multicolumn{2}{|c|}{ Anti-stress AR of MRL } & 0 & 0 & 0 & 20 \\
\hline
\end{tabular}

N o t e. AR - adaptational reactions, RA - reactivation reaction, VLRL, LRL and MRL - respectively, "very low", "low" and "moderate" levels of reactivity of the body. *differs from the results before treatment, $p<0.05$.

peripheral blood leukocyte count per 200 cells, with determination of the nature and tension of general nonspecific adaptational reactions of the body [1]. The tests were done before and after treatment. Statistical processing of results was performed using the nonparametric Wilcoxon-Mann-Whitney test and the fractional estimates.

Results and discussion. The adaptational status of patients before treatment was characterized with the development of stress ARs (14-20\% of cases), ARs of over-activation and tensioned anti-stress ARs of "low" (LRL) and "very low" (VLRL) reactivity levels. This indicated a significant decrease in the activity of the body's defense systems and abnormal neuroimmune regulatory relationships in the development of malignant process in the brain and cervix. RT without xenon did not lead to a noticeable change in the state of patients with BM assessed by severity of pain (Table). Some improvement in the adaptational status was observed only in a quarter of patients who showed the development of the stress areactivity, significantly more favorable compared with stress and over-activation ARs [1] (Table).
Xenon therapy after RT markedly improved all studied indicators. This was demonstrated by pain relief and improved adaptational status of patients - the development of stress areactivity or anti-stressor ARs of "moderate" reactivity levels (MRL) in $70 \%$ of cases $(p<0.05)$ (Table).

Similar results were obtained in patients with CC. Surgery caused a predictable decline in the adaptational status of patients expressed by a significantly increased rates of stress ARs - from 14 to $75 \%$ of cases $(p<0.05)$. Xenon notably reduced negative effects of the surgery. The rate of anti-stressor ARs increased from 22 to $80 \%(p<0.05)$, compared to the values on the first day after surgery. This was accompanied by a decreased analgesic use, from $56 \%$ (in the group without xenon) to $11 \%$ of cases $(p<0.05)$.

Conclusions. The analgesic effect of xenon in neuro-oncological and gynecological patients is associated with an improvement in the characteristics of integral reactions, reflecting the state of neuroimmune processes and reducing of the damaging effect of a special antitumor treatment.

\section{References}

1. Garkavi LH. Activation therapy. Rostov-on-Don; 2006. 256 p. (In Russ.)

2. Grace PM, Hutchinson MR, Steven F, et al. Pathological pain and the neuroimmune interface. Nature Rev. Immunol. 2014;14:217-231.

3. Kitiashvili IZ, Burov NE, Sribnyi IV, et al. Postoperative dynamics of blood cytokine levels depending on applied general anesthesia variants. Cytokines and inflammation. 2005;4(4):27-33. (In Russ.) 